\title{
USING THE MODELLING AND SIMULATION TECHNIQUES TO IMPROVE THE MANAGEMENT OF SMES BELONGING TO REGIONAL CLUSTERS
}

\author{
Mihail, TîTUU ${ }^{1}$, Constantin, OPREAN ${ }^{2}$, Claudiu, PIRNAU ${ }^{3}$ and Ștefan, ȚÎTUU ${ }^{4}$ \\ 1,2 "Lucian Blaga" University of Sibiu, Romania, e-mail mihail.titu@ulbsibiu.ro \\ ${ }^{3}$ The University of South East Europe Lumina Bucharest, Romania \\ 4 "Iuliu Hațieganu" University of Medicine and Pharmacy Cluj Napoca, Romania
}

\begin{abstract}
The efficiency of exploiting the software takes on new dimensions under the conditions of integrated exploitation at the level of process and structural organization of SMEs found within the regional strategic alliances. The modeling and simulation of the leadership and regulation processes of the supply, sales and production flows imply a complex display of forces between the different partners of the logistic chain which can be supported by the existence of some data bases developed based on information partnership whose purpose is to counterattack the communication barriers and to ensure a flow and flexibility of the entire logistic flow. The modeling and simulation of the non-industrial processes can lead to the increase of the efficient development of the rural areas and small urban areas through agro-tourism, combining elements that are specific to some fields such as agriculture, ecology, merchandise/people transportation and tourism.
\end{abstract}

KEY WORDS: Cluster, Modeling and simulation, Network, Databases, Eco-Bio-Economy, Logistics.

\section{INTRODUCTION}

The evolution of clusters has gone through three stages, each of these stages adding a plus of novelty in order to increase their efficiency and effectiveness - from the "Triple helix" to the "Four leaf clover" and "Five for all" - in the context of the complex interactions between the effects of knowledge specific to the new economy, the effects of the economic crisis and the effects of the smart integrated sustainable development. The novelty element specific to the "Five for all" cluster consists in its management ensured by means of a regional network (called "Smart network"), made out of a number of five specialists: Knowledge Manager; Senior Sustainable Development Manager; Migration Manager; Facilities Manager; Transverse Manager. The activity of this managerial team for sustainable development needs to be corroborated permanently with the principles of sustainable development (the decisions of the UNCSD - United Nations Conference on Sustainable Development 2012 Rio+20) and the principles of the transversal management mainly based on making and supporting the relationship systems. The implementation of this new model is based on the defining characteristics of the three cluster categories that are going to be integrated in order to obtain an eco-bio-economic cluster: Bio-cluster; Cluster for research in education; sustainable development and social inclusion; Regional innovative cluster. The methodology of creating the new eco-bio-economic cluster (using the "Five for All" model presented in figure 1), is based on an algorithm revealed by a number of nine stages: Identifying the main work systems at regional level; Identifying the main work systems based on industrial-agricultural production; Identifying the SMEs with industrial/agricultural production activities; Identifying the SMEs that represent the industry/ies relevant for the analyzed region; identifying the main sectorial concentrations (industrial parks, integrated business complexes, business incubators, etc.); Identifying the SMEs that activate in the field of services rendering; Identifying the country households with SME status; Identifying the country households with FA (Family association status); Identifying local craftsmen and the craftsmanship activities developed at regional level [1].

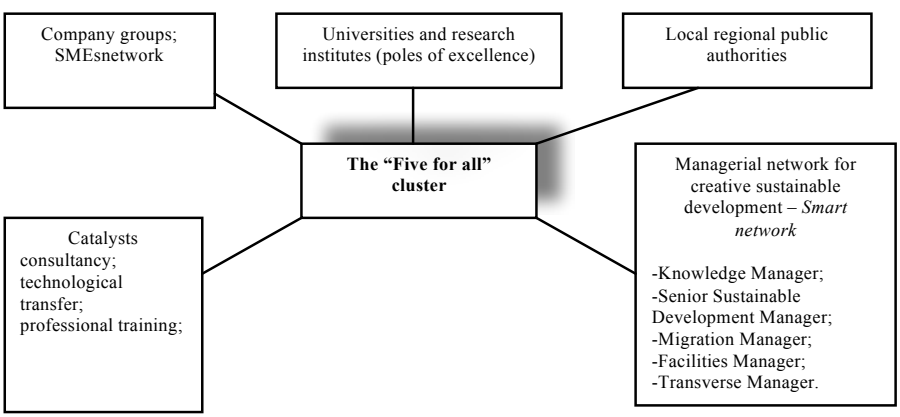

Figure 1. Eco-bio-economic cluster based on the "Five for all" model

The connection between the competitive advantages of the ecobio-economic clusters and the sustainable development process can be represented according to figure 2 . 


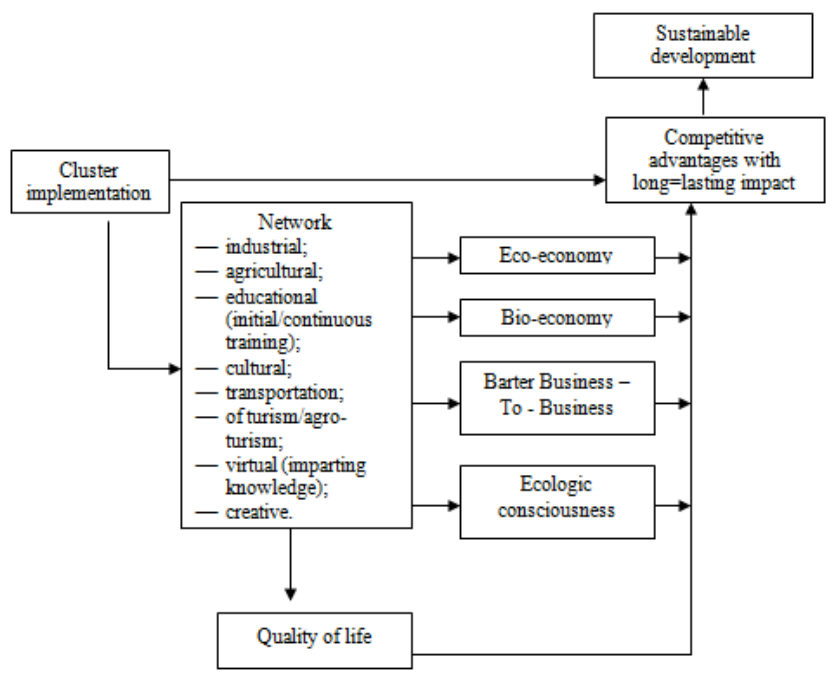

Figure 2. The connection between the competitive advantages of the eco-bio-economic clusters and the sustainable development process

The competitive advantages, found in a tight connection with the organizational performance, are generated through the competitive factors and can be counterbalanced by the noncompetitive advantages (due to some wrong policies/regulations).

The competitive advantages of the eco-bio-economic type of strategic alliances will be able to be amplified through the contribution of the community members' creativity, community made out of individuals who want a "creative cluster", which will obtain notable results especially in the process of creating new work places [2].

\section{THE ROLE OF SIMULATIONS IN THE MANAGEMENT PROCESS}

Simulation represents a relatively new technique of "virtual" realization of experiences. Etymologically, the word "simulation" comes from the Latin 'simulatio' meaning the capacity to reproduce, to represent or to imitate something.

Simulation is an efficient multidisciplinary field of investigation, mainly based on mathematics, the theory of systems and computer science. Simulation offers a tool with a scientific character, deep and exact, at the same time offering the possibility to study the real state of the systems [3].

The main advantages of using simulations compared with the mathematical (analytical) models, are the following:[4]

- Simulation is flexible. Any situation, regardless of the degree of complexity, can be researched by means of independent simulation;

- Simulation can be used to answer to a variety of questions. It is possible, for example, to evaluate the waiting times, the occupation rates and the error percentages which exist in the case of the same model;

- Simulation is easy to understand. Essentially, it is nothing else then a re-enactment of the modeled situations. As opposed to many analytical models, the simulation program users do not have to have a high degree of expertise and a high volume of knowledge.

The Arena Program is ranked in the "Top 10" of PLM (Product Lifecycle Management) suppliers made by the BusinessSoftware.com site. Arena offers the benefits of a PLM closedbased type of solution, namely: economies using costs, reduced security risks, relatively simple ways/rules of usage and a faster way to implement new services/products.

More so, Arena represents an attractive solution form a financial point of view for small and medium enterprises and at the same time o solution, robust enough to satisfy the demands of multinational corporations. Arena Simulation Software represents a tool of administering the production flows in an enterprise, which can allow the realization of on-line connections between simulation techniques and different external applications.

By including the synchronization characteristics of the times resulted after a simulation process with the normed times of external systems and through the on-line connection with it, the usage of the Arena program presents the following advantages: [5]

- The control and monitor of systems;

- Simulation of the basic processes;

- Training facilities;

- The logical control testing.

The primal objective of processes' simulation is represented by the passing from the current state ("as is") to the desired one ("to be") and it is done through:

- the verification of the new studies, projects, programs and systems before allocating and consuming the resources;

- determining some new cause-effect type of relationships; comprising or extending time;

- determining the most important variables for accomplishing the purpose and their manner of intercorrelation;

- identifying the blocks in the material, information and production flow.

\section{HYPOTHETICAL MODEL FOR THE AGGREGATION OF THE ECO-BIO- LOGISTIC COMPONENTS USING THE ARENA SIMULATION}

Taking into consideration the eco-bio-functional characteristics of Dambovita County, the county's ranking on top places in the fruit and vegetable production, as well as in the area of animal production, the elements which have led to the county's quotation as main supplier of perishable products for the South-Muntenia Developing Region, we can conclude that at the level of this county there are optimal conditions for the ecobio-economic development, especially regarding the bio-mass. [6]

In the context of the transition toward the Knowledge Based Bio-Economy (KBBE), as well as the specific conditions regarding the aggregation of the eco-bio-logistic components at the level of a county, the activities inside an eco-bio-economic cluster have been modeled. It was considered that the vegetable mass collected from the localities B, C and D (in this case Razvad, Ulmi and Aninoasa) is transported with the help of vans in locality A (Targoviste) in order to sort and bale it. The resulted bales are transported with a truck to the refinery in locality E (Ploiesti), in order to obtain the bio-fuels necessary for the reduction of $\mathrm{CO}_{2}$ emissions. The implementation chart of the practical application is presented in figure 3 . 


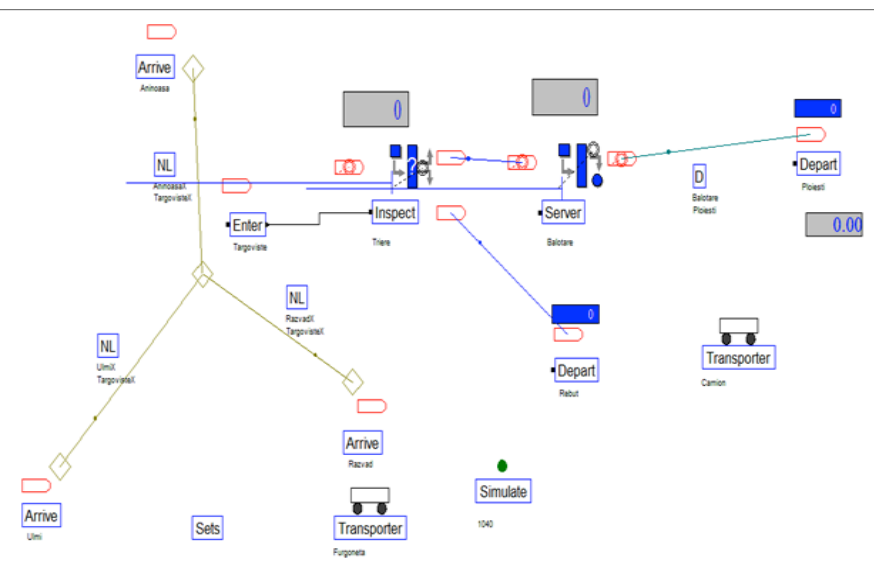

Figure 3. The modeling of the collecting, sorting, baling and transportation of the vegetable bio-mass

The data base which contains the tables and the relations existing between them uses the SGBD Microsoft Access allowing the management of all values necessary for the simulation. The tables have main keys for making the interconnection of the stored and processed values within the simulation. Synthetic, the tables used by the Arena simulator looks like in figure 4.

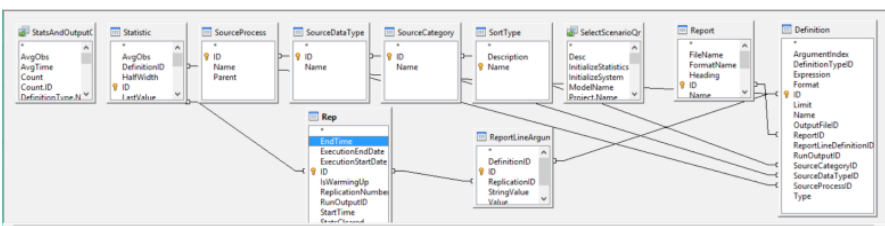

Figure 4. The main tables of the database corresponding to the simulated process

The selective description of the simulated process is done in the Definition chart and the values corresponding to the Name field designed to be used in the simulator are the ones in figure 5 .

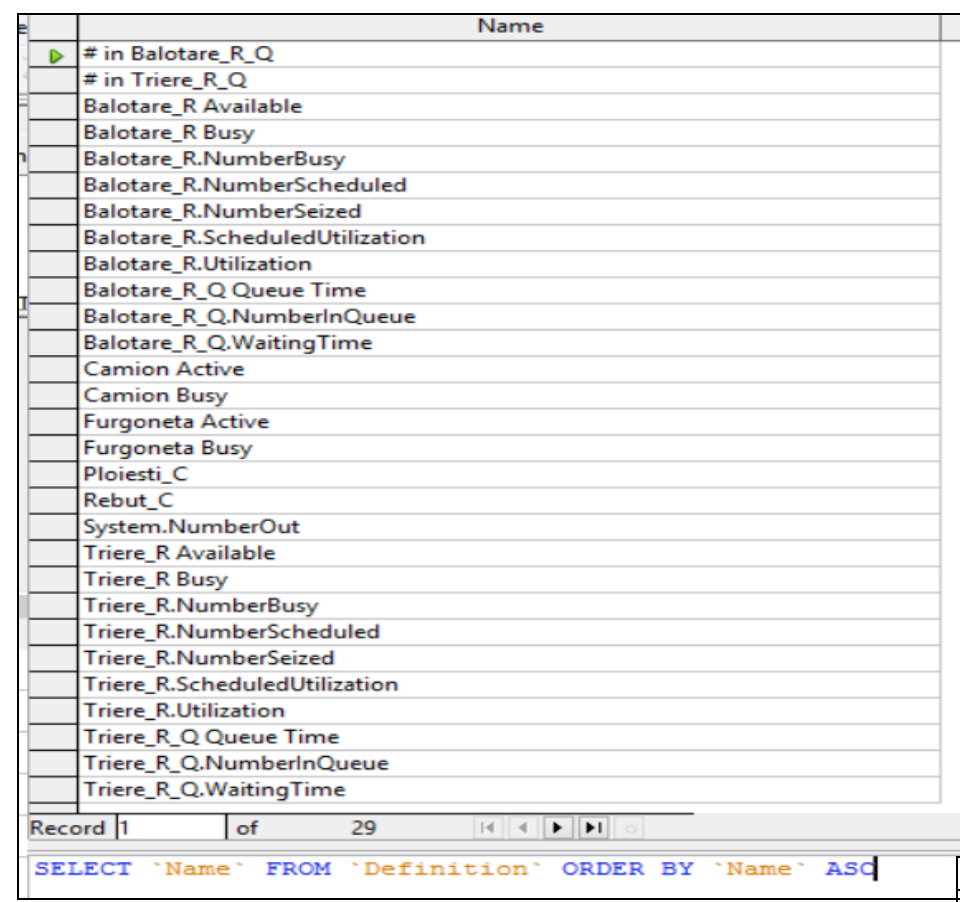

Figure 5. The values of the Name field in the Description chart

For making the modeling process the following models have been used:
- The Sets Model - necessary for creating some different images (in the animation process) for the vegetable mass coming from different (local) sources.

- The Transporter Model - allows the modeling of the logistic system used in order to transport the vegetable mass. There have been two models of this type used, necessary to model the logistic of three vans. It was considered that the initial state of all transportation means used is "active".

- The Arrive model - allows the modeling of the collecting process of the vegetable bio-mass in the three localities B, $\mathrm{C}$ and $\mathrm{D}$ as well as the loading frequency of the vans (Time Between)

- The Insepct Model - is used to sort the vegetable mass collected in locality A, operation which takes 2 hours. It was considered that $2 \%$ of the merchandise is noncorresponding (0.02 - Failure probability) being sent to the waste collecting point, at 2 hours intervals. The rest of the vegetable mass is sent to the baling point, at 3 hours intervals.

- The Server Model - is used for the modelling of the baling process (Station - Baling), establishing the existence/ necessity of the following resources: a single work point afferent to the baling operation $($ Capacity $=1)$ and a duration of 5 hours (Process Time $=5$ ).

- The NetworkLink Model - used to model the back-forth movements of the 3 vans between the source localities $B$, $\mathrm{C}$ and $\mathrm{D}$, namely the destination (A).

- The Distance Model - defines the distance, which is travelled by the truck between the baling station in locality A and the refinery in locality E.

- The Simulate Model - defines the time interval for which the activities related to the collecting and transportation of the bio-mass is monitored.

- The Depart Model - is used to model the system outputs allowing both the registration of the system outputs and the average stationary duration of the entities in the system. For the vegetable mass, the system output is done at the waste collection station $\mathrm{F}$ and for the bales destined for the refinery, the output is done in a station in locality E (Ploiesti)

\section{STATISTICAL PROCESSING OF THE SIMULATION PROCESS'S RESULTS}

Based on the simulations done through the Arena application's modules, one will be able to generate a managerial model necessary for making the elements involved in the production process function more efficiently by delivering the reports regarding the times, the degree of usage of the resources and the entities coming out of the system.

In order to obtain a set of output data which will be able to be analyzed from a managerial and statistic point of view, we have made eight simulations. The main input data are the ones in table 1.

Table 1. Input data for the simulation of bio-mass collection and transportation

\begin{tabular}{|c|c|c|c|c|c|c|c|c|}
\hline Input data & S1 & S2 & S3 & S4 & S5 & S6 & S7 & S8 \\
\hline $\begin{array}{c}\text { Loading time } \\
\text { van B }\end{array}$ & $\begin{array}{c}48 \\
\text { hours }\end{array}$ & $\begin{array}{c}8 \\
\text { hours }\end{array}$ & $\begin{array}{c}8 \\
\text { hours }\end{array}$ & $\begin{array}{c}8 \\
\text { hours }\end{array}$ & $\begin{array}{c}8 \\
\text { hours }\end{array}$ & $\begin{array}{c}8 \\
\text { hours }\end{array}$ & $\begin{array}{c}6 \\
\text { hours }\end{array}$ & $\begin{array}{c}6 \\
\text { hours }\end{array}$ \\
\hline $\begin{array}{c}\text { Loading time } \\
\text { van C }\end{array}$ & $\begin{array}{c}40 \\
\text { hours }\end{array}$ & $\begin{array}{c}8 \\
\text { hours }\end{array}$ & $\begin{array}{c}8 \\
\text { hours }\end{array}$ & $\begin{array}{c}8 \\
\text { hours }\end{array}$ & $\begin{array}{c}8 \\
\text { hours }\end{array}$ & $\begin{array}{c}8 \\
\text { hours }\end{array}$ & $\begin{array}{c}8 \\
\text { hours }\end{array}$ & $\begin{array}{c}7 \\
\text { hours }\end{array}$ \\
\hline $\begin{array}{c}\text { Loading time } \\
\text { van D }\end{array}$ & $\begin{array}{c}56 \\
\text { hours }\end{array}$ & $\begin{array}{c}8 \\
\text { hours }\end{array}$ & $\begin{array}{c}8 \\
\text { hours }\end{array}$ & $\begin{array}{c}8 \\
\text { hours }\end{array}$ & $\begin{array}{c}8 \\
\text { hours }\end{array}$ & $\begin{array}{c}8 \\
\text { hours }\end{array}$ & $\begin{array}{c}10 \\
\text { hours }\end{array}$ & $\begin{array}{c}8 \\
\text { hours }\end{array}$ \\
\hline
\end{tabular}




\begin{tabular}{|c|c|c|c|c|c|c|c|c|}
\hline Input data & S1 & S2 & S3 & S4 & S5 & S6 & S7 & S8 \\
\hline $\begin{array}{l}\text { No. of trucks } \\
\text { used }\end{array}$ & 1 & 2 & 2 & 2 & 1 & 3 & 3 & 2 \\
\hline $\begin{array}{c}\text { Average } \\
\text { speed of a } \\
\text { truck }\end{array}$ & $\begin{array}{c}50 \\
\mathrm{~km} / \mathrm{h}\end{array}$ & $\begin{array}{c}60 \\
\mathrm{~km} / \mathrm{h}\end{array}$ & $\begin{array}{c}50 \\
\mathrm{~km} / \mathrm{h}\end{array}$ & $\begin{array}{c}50 \\
\mathrm{~km} / \mathrm{h}\end{array}$ & $\begin{array}{c}50 \\
\mathrm{~km} / \mathrm{h}\end{array}$ & $\begin{array}{c}50 \\
\mathrm{~km} / \mathrm{h}\end{array}$ & $\begin{array}{c}50 \\
\mathrm{~km} / \mathrm{h}\end{array}$ & $\begin{array}{c}60 \\
\mathrm{~km} / \mathrm{h}\end{array}$ \\
\hline $\begin{array}{c}\text { Rebuts } \\
\text { probability }\end{array}$ & 0,02 & 0,015 & 0,02 & 0,01 & 0,01 & 0,01 & 0,01 & 0,015 \\
\hline $\begin{array}{l}\text { Sorting } \\
\text { duration }\end{array}$ & $\begin{array}{c}2 \\
\text { hours }\end{array}$ & $\begin{array}{c}0,3 \\
\text { hours }\end{array}$ & $\begin{array}{c}2 \\
\text { hours }\end{array}$ & $\begin{array}{c}0,5 \\
\text { hours }\end{array}$ & $\begin{array}{c}0,5 \\
\text { hours }\end{array}$ & $\begin{array}{c}0,5 \\
\text { hours }\end{array}$ & $\begin{array}{c}0,35 \\
\text { hours }\end{array}$ & $\begin{array}{c}0,4 \\
\text { hours }\end{array}$ \\
\hline $\begin{array}{c}\text { Sorting- } \\
\text { baling } \\
\text { intervals }\end{array}$ & $\begin{array}{c}3 \\
\text { hours }\end{array}$ & $\begin{array}{c}3 \\
\text { hours }\end{array}$ & 1 hour & $\begin{array}{c}3 \\
\text { hours }\end{array}$ & $\begin{array}{c}3 \\
\text { hours }\end{array}$ & $\begin{array}{c}3 \\
\text { hours }\end{array}$ & $\begin{array}{c}2 \\
\text { hours }\end{array}$ & $\begin{array}{c}2 \\
\text { hours }\end{array}$ \\
\hline $\begin{array}{l}\text { Waste sorting } \\
\text { intervals }\end{array}$ & $\begin{array}{c}2 \\
\text { hours }\end{array}$ & $\begin{array}{c}2 \\
\text { hours }\end{array}$ & $\begin{array}{c}5 \\
\text { hours }\end{array}$ & $\begin{array}{c}2 \\
\text { hours }\end{array}$ & $\begin{array}{c}2 \\
\text { hours }\end{array}$ & $\begin{array}{c}2 \\
\text { hours }\end{array}$ & $\begin{array}{c}2 \\
\text { hours }\end{array}$ & $\begin{array}{c}2 \\
\text { hours }\end{array}$ \\
\hline $\begin{array}{l}\text { Duration of } \\
\text { simulation }\end{array}$ & $\begin{array}{l}1480 \\
\text { hours }\end{array}$ & $\begin{array}{l}1040 \\
\text { hours }\end{array}$ & $\begin{array}{c}360 \\
\text { hours }\end{array}$ & $\begin{array}{l}1040 \\
\text { hours }\end{array}$ & $\begin{array}{l}1040 \\
\text { hours }\end{array}$ & $\begin{array}{l}1040 \\
\text { hours }\end{array}$ & $\begin{array}{l}1480 \\
\text { hours }\end{array}$ & $\begin{array}{l}1480 \\
\text { hours }\end{array}$ \\
\hline
\end{tabular}

The output data, which resulted from the simulations are mentioned in table 2 .

Table 2. Output data belonging to bio-mass collection and transportation

\begin{tabular}{|c|c|c|c|c|c|c|c|c|}
\hline he simulated output data & $\begin{array}{l}\mathrm{S} \\
1\end{array}$ & $\begin{array}{l}\mathrm{S} \\
2\end{array}$ & $\begin{array}{l}\mathrm{S} \\
3 \\
\end{array}$ & $\begin{array}{l}\mathrm{S} \\
4 \\
\end{array}$ & $\begin{array}{l}\mathrm{S} \\
5\end{array}$ & $\begin{array}{l} \\
6 \\
\end{array}$ & $\begin{array}{l}S \\
7\end{array}$ & $\begin{array}{l}\mathrm{S} \\
8\end{array}$ \\
\hline $\begin{array}{l}\text { 1e average waiting time on } \\
\text { baling [hours] }\end{array}$ & 0.65 & 0.06 & 0 & 0.44 & 0.44 & 0.44 & 0.13 & 0.14 \\
\hline $\begin{array}{l}\text { 1e average waiting time on } \\
\text { sorting [hours] }\end{array}$ & 0.3 & 0.1 & 1.6 & 0.17 & 0.17 & 0.17 & 0.02 & 0.02 \\
\hline $\begin{array}{l}\text { Taximum waiting time on } \\
\text { baling [hours] }\end{array}$ & 6 & 0.2 & 0 & 0.91 & 0.91 & 0.91 & 1.06 & 1.01 \\
\hline $\begin{array}{l}\text { Taximum waiting time on } \\
\text { sorting [hours] }\end{array}$ & 3.41 & 0.3 & 3.41 & 0.5 & 0.5 & 0.5 & 0.35 & 0.4 \\
\hline $\begin{array}{c}\text { 1e degree of occupation on } \\
\text { baling [\%] }\end{array}$ & 31 & 18 & 4 & 37 & 37 & 37 & 39 & 42 \\
\hline $\begin{array}{c}\mathrm{e} \text { degree of occupation on } \\
\text { sorting [\%] }\end{array}$ & 13 & 11 & 74 & 19 & 19 & 19 & 14 & 17 \\
\hline $\begin{array}{c}\text { No. of entities at the } \\
\text { Refinery" station [type } 2 \\
\text { bales] } \\
\end{array}$ & 92 & 377 & 125 & 381 & 255 & 381 & 569 & 623 \\
\hline $\begin{array}{l}\begin{array}{l}\text { No of rejected entities } \\
\text { (rebut) [type } 1 \text { bales] }\end{array} \\
\end{array}$ & 3 & 9 & 5 & 5 & 5 & 5 & 7 & 15 \\
\hline $\begin{array}{l}\text { tverage down-time in the } \\
\text { ystem of an entity [hours] }\end{array}$ & 21.19 & 14.67 & 16.81 & 15.98 & 186.19 & 15.32 & 13.67 & 13.65 \\
\hline $\begin{array}{c}\text { No. of entities passed } \\
\text { ough the "Sorting" station } \\
\text { [type } 1 \text { bales] } \\
\end{array}$ & 95 & 390 & 134 & 390 & 390 & 390 & 579 & 642 \\
\hline $\begin{array}{l}\text { No. of entities passed } \\
\text { rough the "Baling" station } \\
\text { [type } 2 \text { bales] }\end{array}$ & 92 & 378 & 127 & 382 & 382 & 382 & 571 & 626 \\
\hline $\begin{array}{l}\text { verage no of system output } \\
\text { entities [type } 2 \text { bales] }\end{array}$ & 95 & 386 & 130 & 386 & 260 & 386 & 576 & 638 \\
\hline
\end{tabular}

For the 8 simulations done figure 6 illustrates the graphic representation of the waiting times on baling and sorting and in figures 7 and 8 the occupation degree on the sorting and baling operations and the movement of the entities in the simulated system are pointed out.

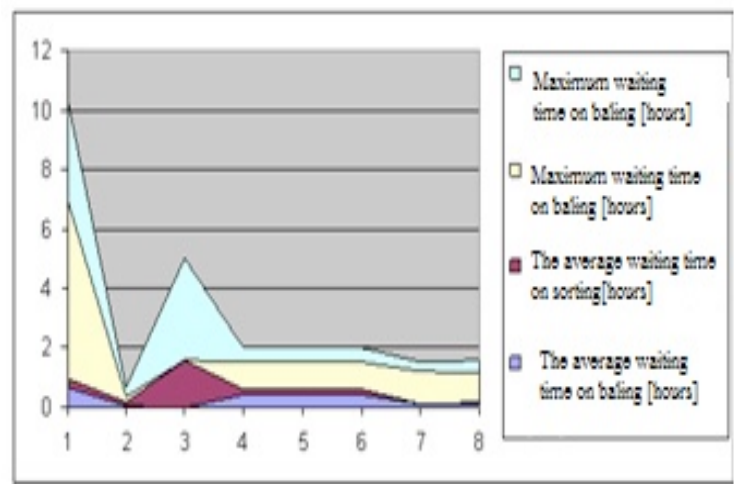

Figure 6. Results regarding times (waiting/down-time)

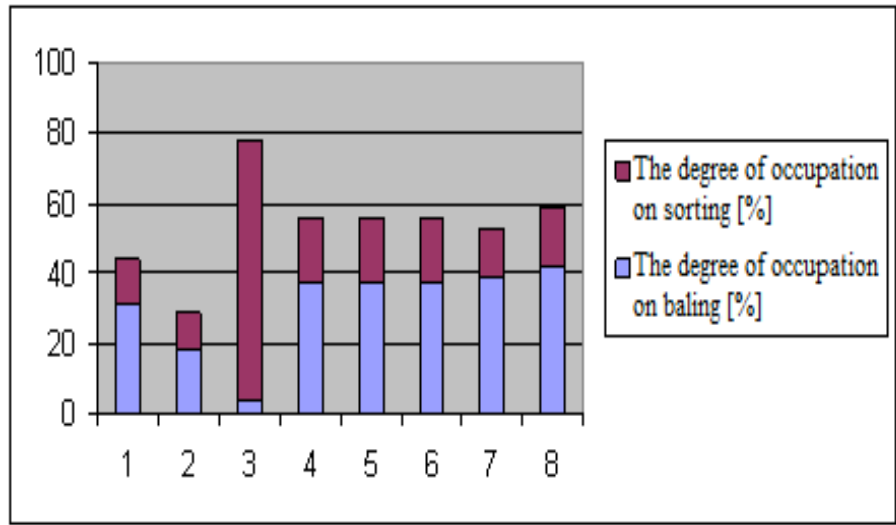

Figure 7. The occupation degree for the sorting and baling degree

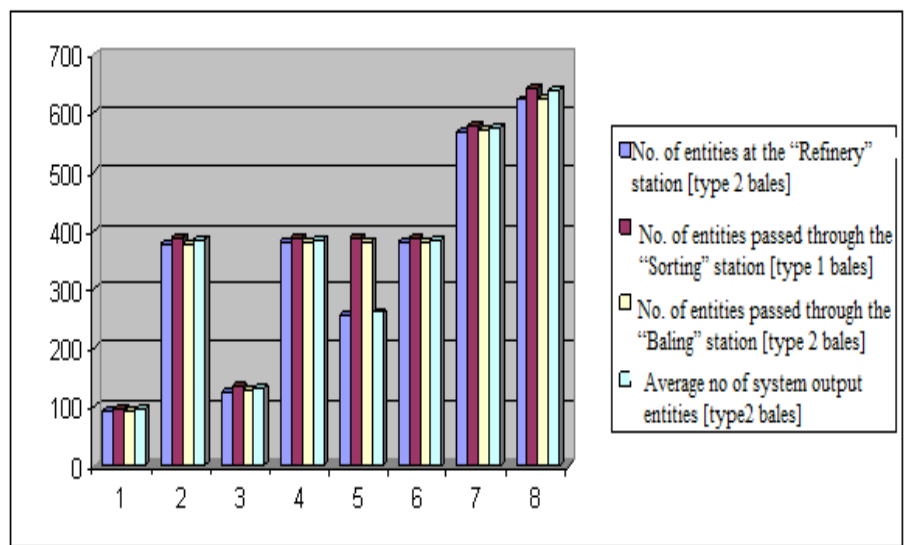

Figure 8. Entities movement in the system

If one considers that the optimal situation is the one for which the simulated values are the closest to the average value of the results, then, according to table 3 , one notices simulation no. $\mathrm{S} 4$, which contains a number of 5 elements close to the average values of the 8 simulations analyzed.

However, the simulations S2, S5 and S6 can be taken into consideration having 4 values close to the average values from the 8 implemented simulations.

Based on the simulations, the following results categories have been obtained:

- the average/maximum waiting time for the baling and sorting operations;

- the occupation degree of each working point;

- the number of entities that have transited each working point;

- the average number of system output entities;

- identification of the number of optimal situations within each operation in the technological process. 
Table 3. The average values of the simulation's results

\begin{tabular}{|c|c|c|c|c|c|c|c|c|c|c|c|}
\hline Name of result & S 1 & S 2 & S 3 & S 4 & S 5 & S 6 & S 7 & S 8 & $\begin{array}{c}\text { Average } \\
\text { values }\end{array}$ & $\begin{array}{c}\text { Minimal } \\
\text { values }\end{array}$ & $\begin{array}{c}\text { Maximal } \\
\text { values }\end{array}$ \\
\hline $\begin{array}{c}\text { Average waiting time on baling } \\
\text { [hours] }\end{array}$ & 0,65 & 0,06 & 0 & 0,44 & 0,44 & 0,44 & 0,13 & 0,14 & 0,2875 & 0 & 0,65 \\
\hline $\begin{array}{c}\text { Average waiting time on sorting } \\
\text { [hours] }\end{array}$ & 0,3 & 0,1 & 1,6 & 0,17 & 0,17 & 0,17 & 0,02 & 0,02 & 0,31875 & 0,02 & 1,6 \\
\hline $\begin{array}{c}\text { Maximum waiting time on } \\
\text { baling [hours] }\end{array}$ & 6 & 0,2 & 0 & 0,91 & 0,91 & 0,91 & 1,06 & 1,01 & 1,375 & 0 & 6 \\
\hline $\begin{array}{l}\text { Maximum waiting time on } \\
\text { sorting [hours] }\end{array}$ & 3,41 & 0,3 & 3,41 & 0,5 & 0,5 & 0,5 & 0,35 & 0,4 & 1,17125 & 0,3 & 3,41 \\
\hline $\begin{array}{l}\text { The degree of occupation on } \\
\text { baling [\%] }\end{array}$ & 31 & 18 & 4 & 37 & 37 & 37 & 39 & 42 & 30,625 & 4 & 42 \\
\hline $\begin{array}{c}\text { The degree of occupation on } \\
\text { sorting [\%] }\end{array}$ & 13 & 11 & 74 & 19 & 19 & 19 & 14 & 17 & 23,25 & 11 & 74 \\
\hline $\begin{array}{c}\text { No. of entities at the "Refinery" } \\
\text { station [type } 2 \text { bales] }\end{array}$ & 92 & 377 & 125 & 381 & 255 & 381 & 569 & 623 & 350,375 & 92 & 623 \\
\hline $\begin{array}{c}\text { No of entities rejected (rebuts) } \\
\text { [type } 1 \text { bales] }\end{array}$ & 3 & 9 & 5 & 5 & 5 & 5 & 7 & 15 & 6,75 & 3 & 15 \\
\hline $\begin{array}{l}\text { Average down-time in the } \\
\text { system of an entity [hours] }\end{array}$ & 21,19 & 14,67 & 16,81 & 15,98 & 186,19 & 15,32 & 13,67 & 13,65 & 37,185 & 13,65 & 186,19 \\
\hline $\begin{array}{l}\text { No. of entities passed through } \\
\text { the "Sorting" station [type } 1 \\
\text { bales] }\end{array}$ & 95 & 390 & 134 & 390 & 390 & 390 & 579 & 642 & 376,25 & 95 & 642 \\
\hline $\begin{array}{l}\text { No. of entities passed through } \\
\text { the "Sorting" station [type } 2 \\
\text { bales] }\end{array}$ & 92 & 378 & 127 & 382 & 382 & 382 & 571 & 626 & 367,5 & 92 & 626 \\
\hline $\begin{array}{l}\text { Average no of system output } \\
\text { entities [type } 2 \text { bales] }\end{array}$ & 95 & 386 & 130 & 386 & 260 & 386 & 576 & 638 & 357,125 & 95 & 638 \\
\hline No of optimal situations & 3 & 4 & 0 & 5 & 4 & 4 & 2 & 1 & & & \\
\hline
\end{tabular}

\section{CONCLUSIONS}

The simulations done in the aggregation process of the eco-biologistic components belonging to the cluster will be able to be adapted in order to develop and optimize the processes specific to the production and stocks management - using the correlation between the sustainable production and the sustainable consumption - necessary for ensuring the quality of life and long-lasting happiness of the society's members respectively, the (industrial or commercial) logistics' management on whose performance the realization of the objectives regarding the sustainable development of the smart organizations, members of the new eco-bio-economic regional clusters, depends. Out of these processes - analyzed and unfolded at regional level - we can mention: the implementation and efficiency of the vegetable bio-mass collection; optimization of the merchandise/people transportation activities; implementing and making the distribution and collection of the different categories of products/wastes (including developing working from home) more efficient; developing the craftsmanship industry in the rural localities belonging to the modern strategic alliances.

\section{REFERENCES}

1. Pîrnau, C. Contributions On Integration Of Knowledge Management In The Sustainable Development Of Small
And Medium - Sized Enterprises, Ph D Thesis, Lucian Blaga University of Sibiu, March, (2015).

2. Țîțu, M.A. Pîrnau, C. Pîrnau, M. Creativity, education and quality for sustainable development, the real support for the Innovative Cluster's European Network, 8th Research/Expert Conference with International Participations „Quality 2013”, Neum, Bosnia \& Herzegovina, June, (2013).

3. Szabo, L. Modelarea sistemelor electromecanice, Universitatea Tehnică din Cluj-Napoca, 2006 Modelling the electro-mechanical systems, Technical University of Cluj-Napoca, (2006).

4. Aalst, W.M.P. Voorhoeve, M. Business Process Simulation, Lecture notes 2II75, Techical University Eindhoven, Netherlands, (2008).

5. www.arenasolutions.com

6. Comşa, D. Bogdan, Al. T. Eco-Bio-Diplomaţia, Academia de Ştiinţe Agricole şi Silvice din România, Bucureşti, 2011 The Eco-Bio-Diplomacy, The Academy for Agricultural and Forestry Sciences in Romania, Bucharest, (2011).

7. Pîrnau, M. General information on the deposits of data, components of business intelligence and data mining technology, Proceedings of the XXIII Miro CAD, International Scientific Conference, University of Miskolc, section Mathematics and Computer Science, ISBN:978963-661-866-7, 978-963-661-872, (2009). 